\title{
Signaling Pathways that Control Cell Proliferation
}

\section{Robert J. Duronio ${ }^{1,2,3}$ and Yue Xiong ${ }^{2,3,4}$}

\author{
${ }^{1}$ Department of Biology and Genetics, University of North Carolina, Chapel Hill, North Carolina 27599 \\ ${ }^{2}$ Program in Molecular Biology and Biotechnology, University of North Carolina, Chapel Hill, North Carolina 27599 \\ ${ }^{3}$ Lineberger Comprehensive Cancer Center, University of North Carolina, Chapel Hill, North Carolina 27599 \\ ${ }^{4}$ Department of Biochemistry and Biophysics, University of North Carolina, Chapel Hill, North Carolina 27599 \\ Correspondence: duronio@med.unc.edu; yxiong@email.unc.edu
}

\section{SUMMARY}

Cells decide to proliferate or remain quiescent using signaling pathways that link information about the cellular environment to the $\mathrm{G}_{1}$ phase of the cell cycle. Progression through $\mathrm{G}_{1}$ phase is controlled by $\mathrm{pRB}$ proteins, which function to repress the activity of $\mathrm{E} 2 \mathrm{~F}$ transcription factors in cells exiting mitosis and in quiescent cells. Phosphorylation of pRB proteins by the $G_{1}$ cyclin-dependent kinases (CDKs) releases E2F factors, promoting the transition to $\mathrm{S}$ phase. CDK activity is primarily regulated by the binding of CDK catalytic subunits to cyclin partners and CDK inhibitors. Consequently, both mitogenic and antiproliferative signals exert their effects on cell proliferation through the transcriptional regulation and ubiquitin-dependent degradation of cyclins and CDK inhibitors.

\section{Outline}

\section{Introduction}

2 Transcriptional regulation of $\mathrm{G}_{1}$ cyclins by mitogenic signals

3 Transcriptional regulation of CDK inhibitors

4 Control of $\mathrm{G}_{1}$ cyclins by the ubiquitinproteasome system
5 Control of $\mathrm{G}_{1} \mathrm{CDK}$ inhibitors by the ubiquitinproteasome system

6 Concluding remarks

References

Editors: Lewis Cantley, Tony Hunter, Richard Sever, and Jeremy Thorner

Additional Perspectives on Signal Transduction available at www.cshperspectives.org 


\section{INTRODUCTION}

Control of cell proliferation generally occurs during the first gap phase $\left(G_{1}\right)$ of the eukaryotic cell division cycle (see Box 1). Multiple signals, ranging from growth factors to DNA damage to developmental cues, influence the decision to enter $S$ phase, when DNA is replicated (Fig. 1). Hence, $G_{1}$ phase cell cycle control is intrinsically linked with a diverse set of pathways controlling differentiation, stem and progenitor cell quiescence, senescence, and responses to a variety of stresses. The decision to enter $S$ phase from $G_{1}$ represents a point of no return that, in the absence of stress such as DNA damage, commits cells to complete the cell cycle and divide, and is therefore tightly controlled. This decision is made at what is called the "restriction point" in mammalian cells and "START" in yeast, after which cells become largely refractory to extracellular signals and will complete $S$ phase and proceed through a second gap phase ( $G_{2}$ phase) and then mitosis. In multicellular organisms, most differentiated cells exit the active cell cycle during $G_{1}$ phase and enter $G_{0}$ phase, in which they remain metabolically active for days or even years, performing specialized functions. Postmitotic nerve and skeletal muscle cells provide good examples. Some $G_{0}$ cells, such

\section{BOX 1. THE EUKARYOTIC CELL CYCLE}

The classical cell cycle comprises four phases- $G_{1}, S, G_{2}$, and $\mathrm{M}$-and is controlled by cyclin-dependent kinases (CDKs) and their cyclin partners. The commitment to divide occurs in $\mathrm{G}_{1}$ phase, which is controlled by cyclin-DCDK $4 / 6$ and cyclin-E-CDK2 at the so-called $\mathrm{G}_{1} / \mathrm{S}$ transition. DNA is then replicated in $\mathrm{S}$ phase. This is followed by a second gap phase, $\mathrm{G}_{2}$, at the end of which cyclin-B-CDK1 controls entry into $\mathrm{M}$ phase (mitosis), when the cell divides. Cells can exit the cell cycle in $G_{1}$ phase and enter $G_{0}$ phase (quiescence). In some cases, they can reenter the cell cycle and begin dividing again (see main text).

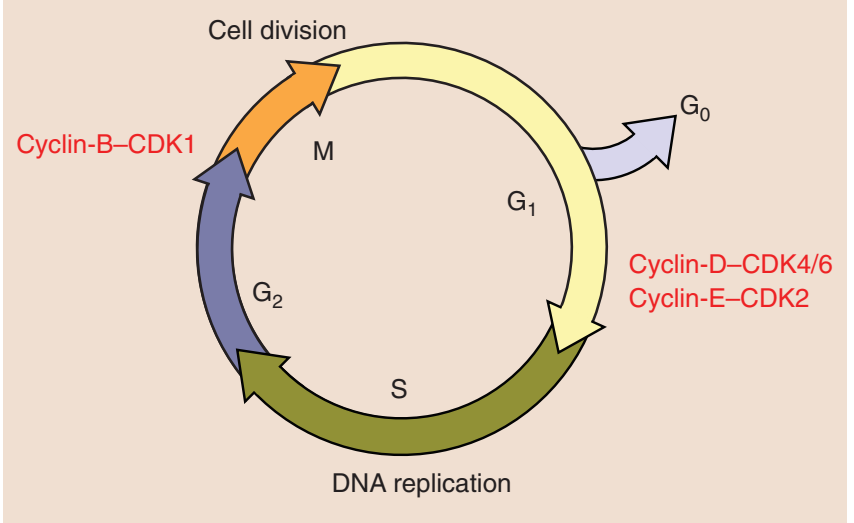

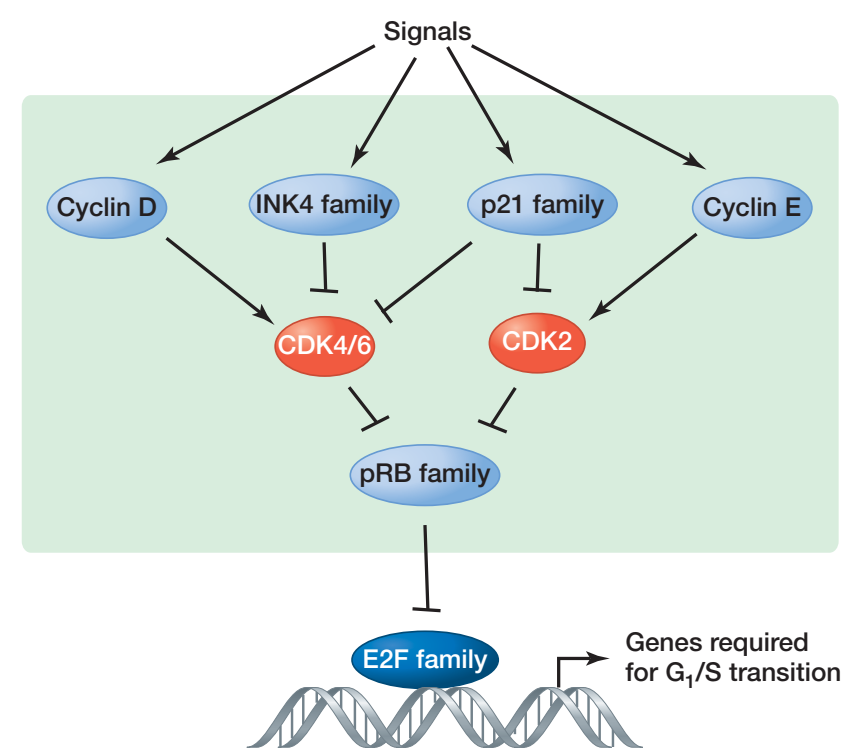

Figure 1. $G_{1}$ cell cycle control by the pRB pathway. Many cellular signaling events are intrinsically linked to $G_{1}$ phase of the cell cycle, which is controlled by the RB pathway. Signaling to the RB pathway and thus $\mathrm{G}_{1}$ control by different cellular processes is achieved mainly through the regulation of cyclins and CDK inhibitors (CKIs). In mammalian cells, mitogenic signals first induce the synthesis of D-type cyclins, leading to activation of cyclin-D-dependent CDK4 and CDK6, and then induce E-type cyclins to activate CDK2. Cyclin-D-CDK4/6 and cyclin-E-CDK2 cooperatively phosphorylate RB-family proteins, derepressing $\mathrm{E} 2 \mathrm{~F}$ to allow transcription of E2F-target genes, thereby promoting the $\mathrm{G}_{1} / \mathrm{S}$ transition. The INK4 proteins specifically inhibit CDK4 and CDK6, whereas the p21 (CIP/KIP) family of CKIs inhibits multiple CDKs. Although the schematic illustration is based on mammalian cells, the regulation of both $G_{1}$ cyclins and CDK inhibitors is evolutionarily conserved.

as quiescent $\mathrm{T}$ cells, can be stimulated by mitogenic signals to reenter the cell cycle.

The restriction point is primarily controlled in mammalian cells by the RB pathway, named after the first tumor suppressor identified, the retinoblastoma protein ( $\mathrm{pRB}$ ) (Weinberg 1995). pRB is a member of a highly conserved family of proteins, encoded by a single gene in the singlecelled green alga Chlamydomonas (MAT3), Caenorhabditis elegans (LIN-35), and Arabidopsis (RBR1); two genes in Drosophila (RBF1 and RBF2); and three genes in mammalian cells (RB1; $p 107$, also known as RBL1; and $p 130$, also known as RBL2) (Weinberg 1995; van den Heuvel and Dyson 2008). Budding yeast cells contain a protein (Whi5) that, although it does not share sequence similarity with pRB, functions at START in a similar manner (Costanzo et al. 2004; de Bruin et al. 2004). pRB proteins are present as hypophosphorylated, active forms in cells exiting mitosis and in quiescent cells, where they use a conserved pocket to bind to LxCxE motifs in numerous chromatin- 
associated proteins and transcription factors, particularly members of the E2F family. pRB proteins negatively regulate the expression of E2F-target genes, many of which are required for entry into and progression through $S$ phase, by recruiting various repressive chromatin regulatory complexes and histone-modifying enzymes or by blocking the transactivation function of E2F proteins. Phosphorylation of the pRB family proteins by $C D K s$ during $G_{1}$ phase causes pRB to dissociate from E2Fs, allowing the transcription of target genes that stimulate progression into $S$ phase (Fig. 1) (Dyson 1998).

The principal kinases that phosphorylate pRB family proteins during $G_{1}$ phase in mammalian cells are three cyclin-dependent kinases $(\mathrm{CDKs})^{5}$ : cyclin-D-dependent CDK4 and CDK6 (Ewen et al. 1993; Kato et al. 1993) and cyclin-E-dependent CDK2 (Akiyama et al. 1992; Hinds et al. 1992). As many as eight distinct mammalian $G_{1}$ CDK-cyclin complexes can be formed from combinatorial association of three D-type cyclins (cyclins D1, D2, and D3) with CDK4 and CDK6 and two E-type cyclins (cyclins E1 and E2) with CDK2, and these phosphorylate as many as 16 sites in pRB proteins (Akiyama et al. 1992; Kitagawa et al. 1996). Regulation of pRB-E2F by $G_{1}$ CDKs has been evolutionarily conserved in plants, worms, flies, and mammals (Inze 2005; van den Heuvel and Dyson 2008). The complexity of the pRB pathway reflects the need to meet the demand to integrate diverse signals from different signaling pathways into a central $G_{1}$ control mechanism. Disruption of this mechanism results in a wide range of developmental defects and human diseases, particularly cancer. Indeed, disruption of $G_{1}$ control probably represents a common event in the development of most types of human cancer (Sherr 1996).

The critical role of $\mathrm{pRB}$ and $\mathrm{G}_{1} \mathrm{CDKs}$ in controlling the $G_{1} / S$ transition is further illustrated by the studies of three DNA tumor viruses: adenovirus, human papilloma virus (HPV), and simian virus 40 (SV40). Although evolutionarily distant from each other, these viruses encode unrelated proteins (E1A in adenovirus, E7 in HPV, and large T in SV40) that bind to and inactivate pRB via an LxCxE motif to promote cell proliferation and viral replication. Primate herpesvirus saimiri and human Kaposi's sarcoma virus encode cyclin D homologs ( $\mathrm{v}$-cyclins) that preferentially bind to and activate CDK6, creating complexes that are resistant to CDK inhibitors (CKIs; see below).

The steady-state levels of CDK2, CDK4, and CDK6 proteins remain relatively constant during the normal cell cycle and in quiescent, aging, and even terminally

${ }^{5} \mathrm{CDKs}$ are a family of kinases that regulate the cell cycle and that require binding to noncatalytic partner proteins termed cyclins for activity. differentiated cells. Signaling pathways that affect $G_{1}$ phase progression thus do not affect CDK levels and instead act mainly through regulation of CDK activity by controlling the abundance of their cyclin partners and a group of CKIs. Although both cyclins and CKIs can be regulated at the level of mRNA stability, translational control, and subcellular localization, the two major control mechanisms are transcriptional regulation and ubiquitin-dependent proteolysis. We discuss these mechanisms below, focusing on the regulation of expression and ubiquitylation of $G_{1}$ cyclins and CKIs by different signal transduction pathways.

\section{TRANSCRIPTIONAL REGULATION OF $\mathrm{G}_{1}$ CYCLINS BY MITOGENIC SIGNALS}

\subsection{D-Type Cyclins}

D-type cyclins were simultaneously isolated initially from mammalian cells in a genetic screen for genes capable of complementing $\mathrm{G}_{1}$ cyclin deficiency in yeast, as the product of a gene whose expression is induced by colony-stimulating factor (CSF1), and as the product of the potential oncogene $B C L 1$ that is clonally rearranged and overexpressed in a subset of parathyroid tumors (Matsushime et al. 1991; Motokura et al. 1991; Xiong et al. 1991). These findings provided early evidence linking the activation of a $G_{1}$ cyclin with mitogenic growth factors and implicating abnormal expression of $\mathrm{G}_{1}$ cyclins in tumorigenesis. However, subsequent genetic analyses revealed only a relatively minor role of cyclin-D-dependent CDK activity in cell proliferation and development (Meyer et al. 2000; Kozar et al. 2004 Malumbres et al. 2004), although mouse embryonic fibroblasts (MEFs) from mice lacking CDK4 and CDK6 do have a reduced rate of exiting from quiescence in response to mitogenic stimulation. Hence, the D-type cyclins, although not an obligate component of the cell cycle machinery, couple extracellular mitogenic signals to the $G_{1} / S$ transition (Sherr and Roberts 2004).

The canonical Ras-Raf-MEK-ERK mitogen-activated protein kinase (MAPK) pathway is the best characterized pathway for the activation of cyclin D transcription (Morrison 2012). It stimulates the expression of AP1 transcription factors such as the proto-oncogene products Jun and Fos, which bind directly to an AP1 site in the cyclin D1 promoter (Albanese et al. 1995). D-type cyclins can also be induced by other signaling pathways, including mitogenstimulated Rac and NF- $\mathrm{B}$ signaling, cytokine signaling, signaling by receptors for extracellular matrix (ECM) proteins (e.g., integrins), and the Wnt and Notch pathways (Kopan 2012; Nusse 2012). Multiple transcription factors directly regulate cyclin D genes, including Jun, Fos, STAT3, $\beta$-catenin, and NF- $\mathrm{BB}$ (Fig. 2A). Cyclin D genes are ex- 
R.J. Duronio and Y. Xiong

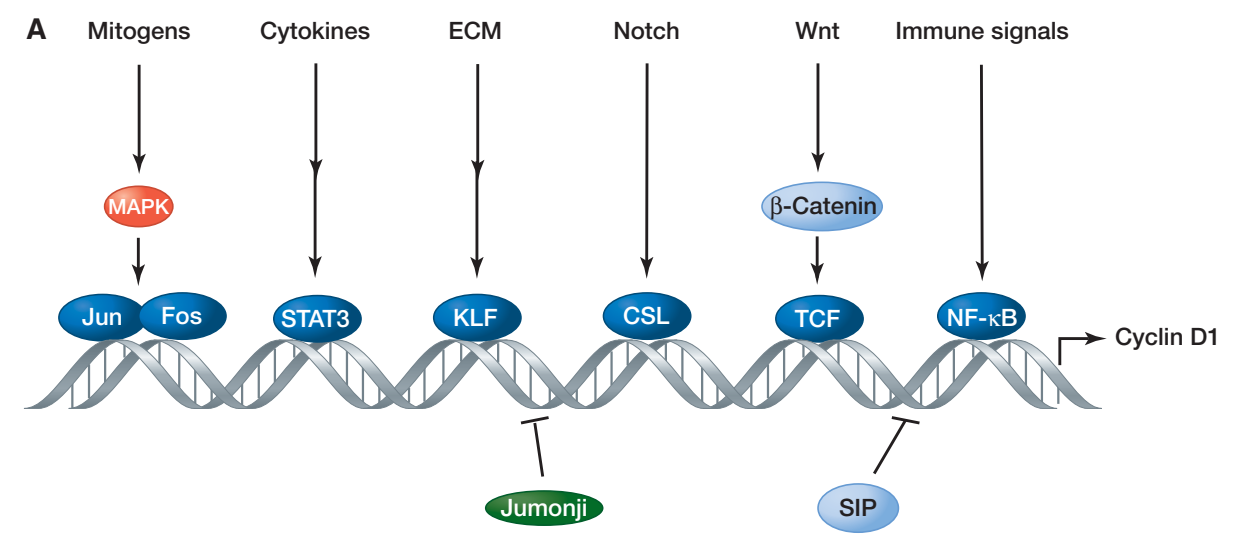

B Cell-type-specific signals

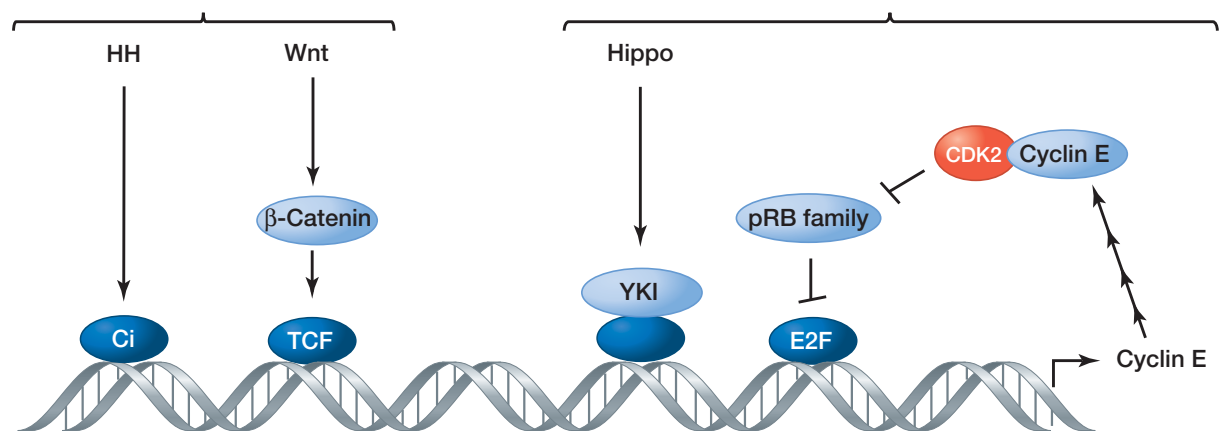

Figure 2. Transcriptional regulation of $\mathrm{G}_{1}$ cyclins. $(A)$ The expression of cyclin genes is tightly regulated at the level of transcription by different signals, including many mitogens. The figure uses human cyclin D1 as an example. $(B)$ Cyclin E expression is also highly regulated and responds to two types of developmental signals, those that are celltype specific and those that all cells use to control proliferation in response to their environment. MAPK, Mitogenactivated protein kinases; ECM, extracellular matrix; STAT, signal transducers and activators of transcription; KLF, Kruppel-like factor; CSL, CBF-1/suppressor of hairless/LAG-1; TCF, ternary complex factor; NF- $\kappa$ B, nuclear factorкB; SIP1, SMAD interacting protein 1; HH, Hedgehog; Ci, Drosophila cubitus interruptus; YKI, Yorkie.

pressed at very low levels in most differentiated tissues, in part because of transcriptional repression by proteins such as Jumonji and SIP (Klein and Assoian 2008). Repression of $G_{1}$ cyclin expression is an important part of cell cycle exit and terminal differentiation, and inappropriate reactivation of D- or E-type cyclins can drive differentiated cells back into S phase (Buttitta et al. 2007; Korzelius et al. 2011).

In contrast to cyclin D repression, inappropriate cyclinD-dependent CDK4/6 activity represents the most frequent alteration of human cyclins in cancer and bears clear pathological significance. Human cyclin D1 is amplified in an estimated $13 \%$ of neoplasms of different types, including breast cancer, esophageal cancer, and lymphoma (Bates and Peters 1995). Mice transgenically expressing cyclin D1 develop mammary gland tumors and conversely are protected against mammary tumors if cyclin D1 is deleted (Wang et al. 1994; Yu et al. 2001). Likewise, CDK4 and CDK6 are also frequently amplified in diverse human cancers. Mouse cells lacking either combination of the three cyclin D proteins or CDK4/6 are more resistant to oncogenic transformation (Sherr and Roberts 2004; Malumbres and Barbacid 2009). These observations indicate that whereas a low level of $G_{1} C D K$ activity is sufficient to support cell proliferation in response to normal physiological levels of mitogens, significantly higher levels of $G_{1} C D K$ activity are required to sustain hyperproliferative stimulation, such as those elicited by activated oncogenes.

\subsection{Cyclin Expression}

Cyclin E is encoded by a single gene in C. elegans (CYE-1) and Drosophila $(C y c E)$ and by two genes in mammalian cells (E1 and E2). The worm and fly cyclin E genes are essential for cell cycle progression and development (Knoblich et al. 1994; Fay and Han 2000). In contrast, mice lacking both cyclin E1 and E2 or CDK2 are viable and display relatively minor defects late in development, owing to compensation by other CDKs (Berthet et al. 2003; Geng 
et al. 2003; Ortega et al. 2003; Parisi et al. 2003). In well-fed proliferating cells, cyclin E expression is cyclical, peaking at the $G_{1} / S$ transition and being low or absent at other times in the cell cycle (Lew et al. 1991; Dulic et al. 1992; Koff et al. 1992). Conversely, MEFs lacking both cyclins E1 and E2 proliferate more slowly than normal cells and have a significantly reduced response to mitogenic stimulation, and cyclin E gene expression is repressed in serum-deprived cells, all of which suggest that cyclin $\mathrm{E}$ responds to growth factors (Herrera et al. 1996; Geng et al. 2003). This regulation is important, because forced overexpression of cyclin $\mathrm{E}$ can shorten $G_{1}$ phase and drive cells into $S$ phase, in part by causing phosphorylation of pRB family proteins (Hinds et al. 1992; Ohtsubo and Roberts 1993; Resnitzky et al. 1994). In vivo, transgenic expression of cyclin $\mathrm{E}$ under the control of the $\beta$-lactoglobulin promoter in mice results in mammary tumorigenesis (Smith et al. 2006), and overexpression of cyclin $\mathrm{E}$ is frequently observed in various human cancers and correlates with increased tumor aggression (Hwang and Clurman 2005). Hence, tight control of the levels of cyclin E is critically important for normal cell physiology and for preventing a neoplastic cell cycle. This notion is supported by biochemical and genetic analyses of the regulation of cyclin $\mathrm{E}$ by phosphorylation and by its regulatory protein FBW7 (see below).

Cyclin E transcription is directly controlled by E2F (Duronio and O'Farrell 1995; Ohtani et al. 1995; Geng et al. 1996). Thus, one important way that signaling regulates cyclin $\mathrm{E}$ is through the $\mathrm{pRB} / \mathrm{E} 2 \mathrm{~F}$ pathway, which also integrates the output from the growth factor signals that control D-type-cyclin-dependent CDK activity. Indeed, if the mouse cyclin $\mathrm{E}$ gene is engineered to respond to the signals that control cyclin D1 gene expression, then cyclin D1 is no longer needed (Geng et al. 1999). Because cyclin$\mathrm{E}-\mathrm{CDK} 2$ can phosphorylate and inactivate $\mathrm{pRB}$, resulting in E2F activity, a positive feedback amplification is an important part of $\mathrm{G}_{1} / \mathrm{S}$ control (Fig. 1B). This helps produce the switch-like behavior needed for unidirectional decisions like the $G_{1} / S$ transition (Xiong and Ferrell 2003; Ferrell et al. 2009).

Control of cyclin E transcription via E2F is a cornerstone of $\mathrm{G}_{1} / \mathrm{S}$ cell cycle control, but the cyclin $\mathrm{E}$ gene also responds directly to signaling pathways. This often occurs when developmental programs coordinate cell cycle progression with cell differentiation. In the Drosophila eye, for example, Hedgehog signaling induces cyclin $E$ at the $G_{1} / S$ transition of the last cell cycle before differentiation of specialized cell types such as photoreceptors (Ingham 2012). The Drosophila CycE gene contains multiple enhancer elements that respond to and integrate various signals (Fig. 2B), including those from the pRB/E2F, Hedgehog and Wnt signaling pathways, in different cell types at different stages of development (Jones et al. 2000; Deb et al. 2008; Ingham 2012).

In Drosophila, CycE is also a target of the growth-inhibitory Hippo pathway (Harvey and Hariharan 2012), whose main target is the inactivation of the transcriptional coactivator Yorkie (YKI) (Huang et al. 2005). Tissue overgrowth upon disruption of the Hippo pathway is accompanied by increased expression of cyclin E, probably through direct regulation of $C y c E$ transcription by transcription factors associated with YKI. In vertebrates, the Hippo-pathway-mediated regulation of cell proliferation appears to be largely mediated by cyclin D1 (Cao et al. 2008).

Transcription of the cyclin E gene thus responds to two types of developmental signals: those that are cell type specific and essential for cell cycle progression (e.g., Hedgehog and Wnt signals), and those that are not cell type specific or strictly essential for cell cycle progression but instead modulate the rate of growth and cell proliferation in response to the cellular environment (e.g., E2F-mediated responses and Hippo) (Fig. 2B).

\subsection{Posttranscriptional Regulation of CDKs}

Posttranscriptional mechanisms also regulate CDK activity in response to various signals. The mitotic CDK, CDK1 (also known as CDC2), is inhibited during interphase by phosphorylation at two adjacent residues within its catalytic pocket, T14 and Y15, and is activated by CDC25-mediated dephosphorylation to bring about a sudden burst of CDK1 activity that triggers mitosis (Rhind and Russel 2012; Hariharan 2013). Both CDK2 and CDK4 are also phosphorylated at analogous residues to mediate the responses to different signals: phosphorylation of T14 and Y15 of CDK2 is important for regulating the timing of DNA replication and centrosome duplication (Zhao et al. 2012), and phosphorylation of Y17 of CDK4 is required for $\mathrm{G}_{1}$ arrest upon UV irradiation, which could cause DNA damage that should be repaired before entry into $S$ phase (Terada et al. 1995).

\section{TRANSCRIPTIONAL REGULATION OF CDK INHIBITORS}

CKIs play an important role in arresting the cell cycle in $\mathrm{G}_{1}$ phase in response to a variety of stimuli, ranging from growth factor deprivation to DNA damage, cellular stress, differentiation, and senescence. Failure to arrest the cell cycle resulting from loss of function of a CKI can cause developmental defects or hyperplasia and tumorigenesis. The first CKI characterized was mammalian p21 (also known as CDKN1A, CIP1, or WAF1), which binds to and 
inhibits the activity of multiple CDK-cyclin complexes (Xiong et al. 1992, 1993a; Harper et al. 1993). The p21 family (also known as the CIP/KIP family) includes three related proteins: p21, p27 (also known as CDKN1B or KIP1), and p57 (also known as CDKN1C or KIP2). A distinct CKI, p16 (also known as INK4A), was isolated around the same time and is a specific inhibitor of CDK4 (Serrano et al. 1993). p16 is the founding member of a separate family of INK4 CKIs that includes three additional proteins: p15 (also known as INK4B), p18 (also known as INK4C), and p19 (also known as INK4D) (Sherr and Roberts 1995).

These two families of CKIs inhibit CDK via different mechanisms. The INK4 proteins bind selectively to the catalytic subunits of two CDKs, CDK4 and CDK6, preventing cyclin binding; and the p21 CKIs bind to the cyclinCDK complex by contacting both subunits via different motifs to block kinase activity and substrate binding. CKIs of both families are localized predominantly in the nucleus in most tissues, but p21 family CKIs have also been frequently observed in the cytoplasm, where they have been linked to CDK-independent functions and tumor development. In particular, reduced nuclear p27 and accumulation of cytoplasmic p27 have been observed in multiple types of human cancers and are associated with poor prognosis of breast cancer (Wander et al. 2011).

The two separate families of multiple CDK inhibitors evolved to meet the increasing need to integrate numerous different antiproliferative signals that can arrest cells in $G_{1}$ phase. Mice lacking CKI genes have various phenotypes, ranging from a compromised DNA damage response ( $p 21$ mutants) to widespread hyperplastic cell proliferation and organomegaly ( $p 18$ - and $p 27$-null mice), spontaneous tumor development ( $p 16$-null mice), and perinatal lethality and widespread developmental defects (in p57-null mice) (Ortega et al. 2002). Furthermore, genetic studies of p21type CKIs in worms and flies have revealed various functions from control of cell cycle progression to cell cycle exit in specific cell types at various times in development (de Nooij et al. 1996; Lane et al. 1996; Hong et al. 1998; Firth and Baker 2005).

One major difference between the two CKI families is their stability. The p21 family inhibitors are intrinsically unstable $\left(t_{1 / 2}<30 \mathrm{~min}\right)$ as a result of ubiquitin-dependent, and in most cases phosphorylation-promoted, proteasomal degradation, and cause a rapid and transient cell cycle arrest, for example, following DNA damage. In contrast, the INK4 proteins are stable $\left(t_{1 / 2}>4-6 \mathrm{~h}\right)$ and are subject to minimal posttranslational regulation. INK4 proteins therefore maintain a long-term or permanent cell cycle arrest in stem, progenitor, senescent, and postmitotic cells. Accordingly, whereas p21 family CKIs are regulated both transcriptionally and posttranscriptionally, the INK4 members are regulated primarily at the level of transcription.

\section{1 p21 Transcription Regulation by p53-Dependent and -Independent Mechanisms}

Cells use signaling pathways to respond to a variety of exogenous and intrinsic stresses that have the potential to damage the genome. The tumor suppressor p53 functions as a transcription factor to activate the expression of many genes involved in stress responses, and defects in p53-mediated stress responses are associated with most types of human cancer. p53-mediated transcriptional activation of $p 21$ following DNA damage was the first identified example of $\mathrm{G}_{1}$-phase regulation of a CKI gene (El-Deiry et al. 1993; Xiong et al. 1993b). Given that none of the other six CKI genes is a direct target of p53, the p53-p21-CDK regulatory module constitutes a major mechanism for DNA-damage-induced cell cycle arrest. Indeed, knocking out the $p 21$ gene compromises the DNA damage response despite having little effect on overall mouse development (Brugarolas et al. 1995; Deng et al. 1995).

Transcriptional regulation of the $p 21$ gene has also been linked to p53-independent cell cycle exit during development. In the Drosophila embryonic epidermis, activation of the dacapo (dap) gene, which encodes a p21-type CKI, triggers cell cycle exit (de Nooij et al. 1996; Lane et al. 1996). In Caenorhabditis elegans, the insulin-like growth factor signaling pathway similarly induces p21 expression in response to starvation, which results in cell cycle arrest in stem cells (Baugh and Sternberg 2006), and Ras/MAPK signaling activates p21 to control cell cycle exit in vulval precursor cells (Clayton et al. 2008). This diversity of responses probably relies on the existence of multiple, modular enhancers for the $p 21$ gene that respond to different signaling pathways (Liu et al. 2002; Meyer et al. 2002).

\subsection{INK4 Repression in Stem and Progenitor Cells}

INK4 genes have distinct expression patterns during development in adult tissues and in response to different conditions (Roussel 1999). p16 is a target of Polycomb group $(\mathrm{PcG})$ transcriptional repressors: deletion of the Polycomb gene Bmil retards cell proliferation, and this is associated with up-regulation of $p 16$ and can be partially rescued by deletion of $p 16$ (van Lohuizen et al. 1991; Jacobs et al. 1999). Furthermore, both PcG repression complexes (PRC1 and PRC2) collaborate with pRB proteins to bind to the p16 locus and trimethylate histone $\mathrm{H} 3$ lysine 27 (H3K27) to repress the expression of p16 (Bracken et al. 2007; Kotake et al. 2007). These findings explain how the up-regulation of p16 in aging stem cells results from de- 
creased expression of Polycomb genes and reveal a negative-feedback loop between p16 and pRB. ${ }^{6}$ In many different types of human tumors, $p 16$ expression is silenced by promoter DNA methylation (Merlo et al. 1995).

Unlike $p 16 \mathrm{mRNA}$, which is undetectable in young tissues and is induced during aging, p18 mRNA is present early in embryogenesis and maintains a high level throughout life in many adult tissues (Zindy et al. 1997). Deletion of p18 in mice results in spontaneous development of various tumors (Franklin et al. 1998; Pei et al. 2009) and increases self-renewing division of hematopoietic stem cells and expansion of mammary luminal progenitor cells (Yuan et al. 2004; Pei et al. 2009). p18 thus seems to suppress tumorigenesis by maintaining a quiescent state in stem and progenitor cells of different organs. GATA3, a transcription factor specifying mammary luminal cell fate, binds to the $p 18$ locus and represses $p 18$ transcription (Pei et al. 2009). It provides an example of a lineage-specifying factor that regulates cell differentiation in part by repressing the expression of an INK4 gene to allow quiescent progenitor cells to exit $G_{0} / G_{1}$ arrest, reenter the cell cycle, and proliferate.

\section{CONTROL OF G ${ }_{1}$ CYCLINS BY THE UBIQUITIN- PROTEASOME SYSTEM}

Like their mitotic counterparts (Hariharan 2013), $G_{1}$ cyclins undergo rapid turnover and are degraded by the ubiquitin-proteasome pathway. This process is tightly regulated through the phosphorylation of cyclins and, in some cases, by proteins that target cyclins to E3 ubiquitin ligases, which provide mechanisms for extracellular factors to signal to the $\mathrm{G}_{1}$-phase cell cycle control machinery.

The level of cyclin E, and associated CDK2 activity, oscillates during the cell cycle (Dulic et al. 1992; Koff et al. 1992). Cyclin E begins to accumulate during the middle of $\mathrm{G}_{1}$ phase (as a result of E2F-mediated transcriptional activation), peaks at the $\mathrm{G}_{1} / \mathrm{S}$ transition, and then is destroyed during $\mathrm{S}$ phase following ubiquitylation. FBW7 (also known as Cdc4 or Ago) is an F-box protein that is the substrate-recognition component of the E3 ubiquitin ligase SCF (also known as CRL1) and recognizes two phosphodegrons in cyclin E: a carboxy-terminal degron centered on T380 and an amino-terminal degron centered

\footnotetext{
${ }^{6}$ Linked to p16, both structurally in the genome and through regulation by Polycomb group proteins, is the product of the $A R F$ tumor suppressor gene, which is transcribed from an alternative promoter and translated in an alternative reading frame from $p 16$. ARF does not share any amino acid sequence similarity with INK4 proteins and instead acts as a p53 activator by binding to and inhibiting the activity of MDM2, the principle E3 ubiquitin ligase for and negative regulator of p53. As a result, any signal, such as oncogenic stimulation, that induces the expression of $A R F$ will stabilize p53 and activate p21, leading to $G_{1}$ cell cycle arrest.
}

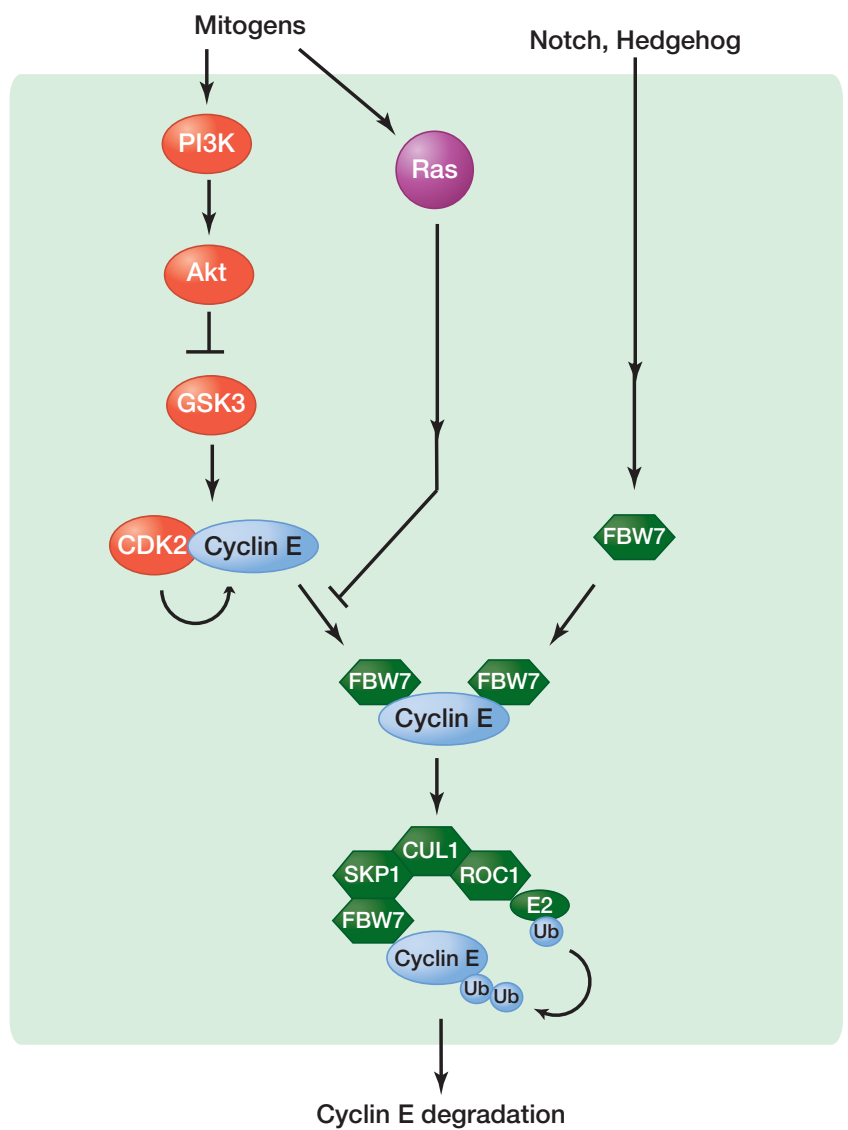

Figure 3. Targeting ubiquitin-dependent degradation of cyclin E. Fbox protein FBW7 specifically recognizes two separate phosphodegrons in cyclin $\mathrm{E}$ and targets cyclin $\mathrm{E}$ for ubiquitin-dependent proteasome degradation by the SCF-FBW7 E3 ligase complex. The phosphorylation of both amino- and carboxy-terminal degrons in cyclin E is catalyzed by GSK3 and CDK2 and creates two separate binding sites for FBW7. Both mitogenic and antiproliferative signals exert their effect on the cell cycle through cyclin E ubiquitylation by inhibiting the activity of GSK3 or stimulating the expression of FBW7, respectively.

on T62 (Fig. 3) (Welcker and Clurman 2008). Both cyclin E degrons are phosphorylated by GSK3 and CDK2 itself, creating two independent FBW7-binding sites. Cyclin-ECDK2 is thought to phosphorylate cyclin E first at T384, creating a "priming phosphate" that is needed for GSK3 to phosphorylate T380 upstream, thus generating the doubly phosphorylated phosphodegron that is specifically recognized by the FBW7 targeting subunit of SCF-FBW7.

Because GSK3 plays critical roles in diverse signals, including those activated by insulin, mitogenic growth factors, Wnts, Hedgehog, and cytokines, GSK3 activity can link the regulation of cyclin $\mathrm{E}$ and thus $\mathrm{G}_{1}$ progression to different signaling pathways. For example, GSK3 is regulated by the phosphoinositide 3 kinase (PI3K)-AKT pathway, which allows a major mitogen signaling pathway (Hemmings 2012) to couple cell growth to $G_{1}$ regulation. 
Transgenic expression of mutant cyclin E (T380A) in mammary glands causes more widespread hyperplasia than that of wild-type cyclin E and promotes p53 loss of heterozygosity and tumorigenesis (Smith et al. 2006). Knock-in mutations that ablate both T62 and T380 result in disruption of cyclin E periodicity, increased cyclin E activity, and abnormal proliferation in multiple cell types (Minella et al. 2008).

Studies of $F b w 7$-mutant mice and loss-of-function mutations of FBW7 in human cancer support a role for SCFFBW7 in negative regulation of cell proliferation by targeting cyclin E, as well as Myc, Notch, and Jun (Welcker and Clurman 2008). Mitogen signaling can also influence the activity of FBW7 itself. In mammalian cells, activated Ras increases cyclin $\mathrm{E}$ levels by inhibiting binding of cyclin $\mathrm{E}$ to FBW7 (Welcker and Clurman 2008), and Notch and Hedgehog signaling suppresses cyclin E accumulation by inducing FBW7 expression in Drosophila eye imaginal discs (Nicholson et al. 2011). Therefore, both oncogenic and developmental signals can control the level of cyclin E protein by regulating components of the E3 ubiquitin ligase that targets cyclin E for destruction (Fig. 3).

Cyclin D is phosphorylated at T286, a site analogous to T380 in cyclin E, and T286 phosphorylation promotes cyclin D destruction (Diehl et al. 1998). Multiple F-box proteins, such as Fbxo41, Fbxw8, SKP2, and Fbxo31, have been implicated in targeting cyclin D for destruction, but the E3 ligase responsible remains to be definitively identified (Kanie et al. 2012). Promoting the destruction of both D- and E-type $\mathrm{G}_{1}$ cyclins by GSK3-mediated phosphorylation, however, could allow cells to effectively couple the PI3K-AKT pathway to $\mathrm{G}_{1}$ cell cycle control. T286-phosphorylated cyclin D1 can also be recognized and stabilized in the nucleus by Pin1, a prolyl isomerase that regulates the function of proteins by causing conformational change of their S/T-phosphorylated forms (Liou et al. 2002).

Progression through $G_{1}$ phase is also controlled by other E3 ligases. In particular, the anaphase-promoting complex (APC), which promotes the ubiquitin-dependent proteasomal degradation of multiple mitotic regulatory proteins, remains active in $G_{1}$ phase to suppress accumulation of mitotic cyclins until cyclin-E-CDK2 is activated at the $G_{1} / S$ transition.

\section{CONTROL OF G ${ }_{1}$ CDK INHIBITORS BY THE UBIQUITIN-PROTEASOME SYSTEM}

Some CKIs are also regulated by the ubiquitin-proteasome pathway. Again, this regulation involves phosphorylation of these CKIs, which provides a mechanism linking extracellular signaling to the $\mathrm{G}_{1}$ cell cycle control machinery.

\subsection{Phosphorylation-Dependent Ubiquitylation and Degradation of a Yeast CKI}

In Saccharomyces cerevisiae, a single CDK, Cdc28, forms multiple B-type cyclin-CDK complexes to drive both S phase and mitosis. Cdc28 is inhibited by Sic1, a CKI that is unrelated in sequence to either the p21 or INK4 family of CKIs. Sic1 is targeted for ubiquitylation (Fig. 4) following phosphorylation by the $\mathrm{G}_{1}$ cyclin-CDK complex ClnCdc28 (Schwob et al. 1994). Inactivation of Sicl rescues the inviability of yeast cells lacking the $G_{1}$ cyclins $C \ln 1$, Cln2, and Cln3 (Schneider et al. 1996), and mutation of CDK phosphorylation sites in Sicl causes stabilization of Sicl and blocks DNA replication. These observations indicate that the primary function of these three $G_{1}$ cyclins, once mitogenically activated, is to promote Sicl ubiquitylation to bring about the $\mathrm{G}_{1} / \mathrm{S}$ transition. Phosphorylated, but not unmodified, Sic1 binds to the F-box protein Cdc4, which, through a linker protein, Skp1, brings Sic1 to the Cul1 (also known as Cdc53)-Roc1 (also known as Rbx or Hrt1) E3 ligase complex for ubiquitylation by the E2 enzyme Cdc34 (Feldman et al. 1997; Skowyra et al. 1997). Nine sites in Sicl are phosphorylated, and each contributes to $\mathrm{Cdc} 4$ binding, with any six being required (Nash et al. 2001). This multisite phosphorylation requirement makes Sic1 ubiquitylation ultrasensitive to the level of $G_{1} C D K$ activity, enabling cells to measure the strength of mitogens and set the level of CDK activity that determines the timing of DNA replication. It transforms a gradual accumulation process, such as protein synthesis during $G_{1}$ phase, into an irreversible switch for the onset of DNA replication. Sic1 is also phosphorylated by its target, the B-type cyclin-CDK complex Clb5-CDK1, which may ensure irreversibility of the $G_{1} / S$ transition once DNA replication has been initiated.

In response to mating pheromones, budding yeast cells arrest their cycle in $G_{1}$ phase and fuse cytoplasms and nuclei to generate a diploid cell. This $\mathrm{G}_{1}$ cell cycle arrest is regulated by the Fus3 MAPK pathway, which leads to phosphorylation and activation of Far1, a second budding yeast CDK inhibitor that is unrelated to Sicl and other CKIs in sequence. Far1 selectively inhibits $\mathrm{G}_{1}$ cyclin-Cdc28, leading to the inhibition of Cln-Cdc28-induced Sic1 degradation and $\mathrm{G}_{1}$ arrest.

The distantly related fission yeast, Schizosaccharomyces pombe, contains a single CKI, Rum1, that is unrelated to Sic1, p21, or INK4 CKIs in sequence. Rum1 inhibits the cyclin B-CDK complex Cdc13-Cdc2 and is an essential $\mathrm{G}_{1}$ regulator whose deletion causes premature S-phase initiation immediately after mitosis (Correa-Bordes and Nurse 1995). Rum1 is degraded following ubiquitylation by the SCF-Pop1 ligase, which uses Pop1, an ortholog of 


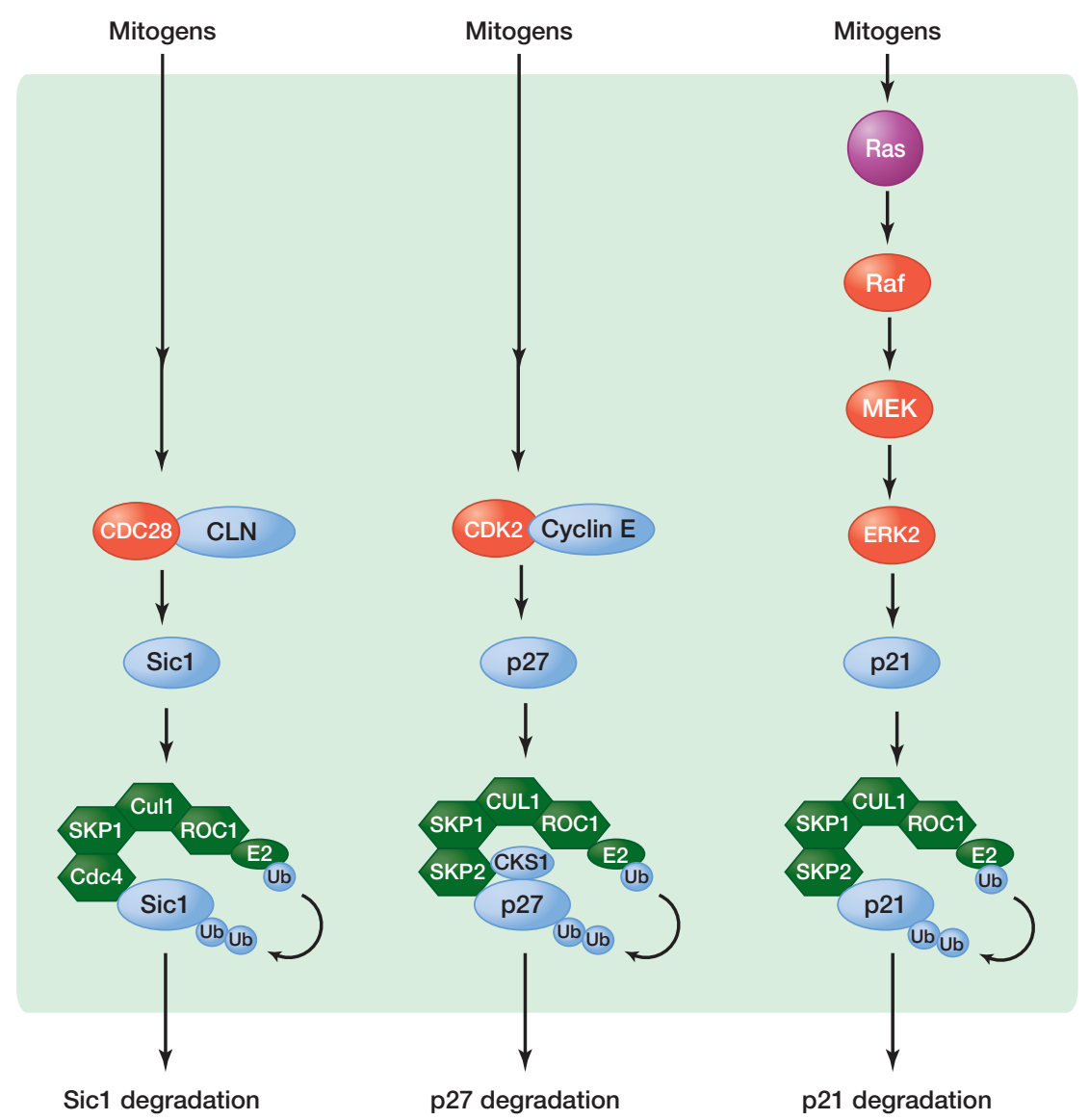

Figure 4. Targeting ubiquitin-dependent degradation of CDK inhibitors. The p21 family of CKIs is regulated by the ubiquitin-proteasome pathway. In many cases, this involves phosphorylation of these CKIs. Phosphorylated CKIs are recognized by F-box proteins such as Cdc4 in budding yeast or SKP2 in human cells, which, through the SKP1 linker protein, recruits the CKI substrate to the SCF E3 ligase for ubiquitylation.

budding yeast Cdc4, to target Rum1 (Kominami and Toda 1997). Hence, the mechanism for targeting $G_{1} C D K$ inhibitors for ubiquitylation has been conserved between two yeast species that are as evolutionarily divergent from each other as either is from animals.

\subsection{Regulation of Mammalian CIP/KIP by E3 Ligases}

The mammalian CKI p27 is also regulated by ubiquitindependent proteolysis (Pagano et al. 1995). p27 and its close relative p57 are phosphorylated by cyclin-E-CDK2 at analogous sites (T187 in p27 and T310 in p57), which promotes their binding to the F-box protein SKP2 and subsequent ubiquitylation by the SCF-SKP2 E3 ligase. The recognition of T187-phosphorylated p27 by SKP2 requires CKS1, a small evolutionarily conserved protein whose function is essential for yeast cell viability and normal mouse development (Fig. 3). A second p27 E3 ligase, KIP1-ubiquitylation-promoting complex (KPC), preferentially recognizes free p27 and is competed off by the binding of cyclin-E-CDK2 (Kamura et al. 2004). Mitogen-stimulated cyclin E expression and thus the formation of the cyclin-E-CDK2 complex may switch cells from KPC-mediated degradation of p27 during early $G_{0} / G_{1}$ transitions to SCF-mediated degradation at the $\mathrm{G}_{1} / \mathrm{S}$ transition. Likewise, p57, which plays important roles in development, is also ubiquitylated by the SCF-SKP2 E3 ligase and a second E3 ligase, SCF-FBL12, containing FBL12. FBL12 is induced by TGF $\beta 1$ and binds only to p57, providing a mechanism for TGF $\beta 1$-induced degradation of p57, but not p27 or p21 (Kim et al. 2008a).

p21 expression oscillates twice during each cell cycle: it is high in $G_{1}$ phase, decreases during $S$ phase, reaccumulates during $G_{2}$ phase, and then decreases at early mitosis. The protein has a very short half-life $(<30 \mathrm{~min})$ and is rapidly turned over by ubiquitin-dependent proteolysis. Several E3 ligases can target p21 ubiquitylation at different phases of the cell cycle in both phosphorylation-dependent and phosphorylation-independent manners. During $G_{1}$ phase, sustained activation of the ERK2 MAPK by mi- 
togenic stimuli such as epidermal growth factor (EGF) results in T57 and S130 phosphorylation on p21, leading to its ubiquitin-dependent degradation (Fig. 3) (Hwang et al. 2009). During S phase, WD40 protein CDT2 and the F-box protein SKP2 target p21 for ubiquitylation by the CRL4-CDT2 and SCF-SKP2 E3 ligases to prevent DNA rereplication (Bornstein et al. 2003; Abbas et al. 2008; Kim et al. 2008b; Nishitani et al. 2008). The SCF-SKP2-mediated p21 ubiquitylation requires S130 phosphorylation by cyclin-E-CDK2 (Bornstein et al. 2003). During early mitosis, Cdc20 binds to p21 and targets it for ubiquitylation by APC. CRL4 also targets p 21 for ubiquitylation after lowdose UV irradiation, to delay the cell cycle, allowing time for optimal DNA repair (Bendjennat et al. 2003; Havens and Walter 2011; Starostina and Kipreos 2012). Hence, the mechanism for targeting $G_{1}$ CKIs for ubiquitylation has been conserved from yeast to animals and links the regulation of CKI stability to signals from different pathways via the phosphorylation of CKI proteins and their targeting molecules.

\section{CONCLUDING REMARKS}

Precise cell cycle regulation is an essential aspect of normal development and adult homeostasis. To achieve this, cells in $G_{1}$ phase integrate inputs from major cellular signaling pathways to decide whether or not to enter $S$ phase, which is an irreversible cell cycle step. This integration of signals is transformed into an appropriate level of CDK activity in large part via changes in the level of cyclins and CKIs achieved through the regulation of both transcription and protein stability. One challenge for the future is to understand how multiple signaling pathways cooperate to precisely regulate cyclin and CKI activity in various cell types, particularly stem cells, in intact tissues. Another is to use this information to develop novel therapeutics for the treatment of cancer, which arises in part because of disruptions to signaling pathways that affect cell cycle regulation.

\section{ACKNOWLEDGMENTS}

We thank Alan Diehl, Andrew Koff, Kun-Liang Guan, Michele Pagano, DJ Pan, and Xin-Hai Pei for discussions, and Tadashi Nakagawa and Ruiting Lin for helping with figure preparation.

\section{REFERENCES}

* Reference is also in this collection.

Abbas T, Sivaprasad U, Terai K, Amador V, Pagano M, Dutta A. 2008. PCNA-dependent regulation of p21 ubiquitylation and degradation via the CRL4Cdt2 ubiquitin ligase complex. Genes Dev 22: 2496-2506.
Akiyama T, Ohuchi T, Sumida S, Matsumoto K, Toyoshima K. 1992. Phosphorylation of the retinoblastoma protein by cdk2. Proc Natl Acad Sci 89: 7900-7904.

Albanese C, Johnson J, Watanabe G, Eklund N, Vu D, Arnold A, Pestell RG. 1995. Transforming p $21^{\text {ras }}$ mutants and c-Ets-2 activate the cyclin D1 promoter through distinguishable regions. J Biol Chem 270: 23589-23597.

Bates S, Peters G. 1995. Cyclin D1 as a cellular proto-oncogene. Semin Cancer Biol 6: 73-82.

Baugh LR, Sternberg PW. 2006. DAF-16/FOXO regulates transcription of cki-1/Cip/Kip and repression of lin-4 during C. elegans L1 arrest. Curr Biol 16: 780-785.

Bendjennat M, Boulaire J, Jascur T, Brickner H, Barbier V, Sarasin A, Fotedar A, Fotedar R. 2003. UV irradiation triggers ubiquitin-dependent degradation of $\mathrm{p} 21^{\mathrm{WAF} 1}$ to promote DNA repair. Cell 114: 599-610.

Berthet C, Aleem E, Coppola V, Tessarollo L, Kaldis P. 2003. Cdk2 knockout mice are viable. Curr Biol 13: 1775-1785.

Bornstein G, Bloom J, Sitry-Shevah D, Nakayama K, Pagano M, Hershko A. 2003. Role of the SCFSkp2 ubiquitin ligase in the degradation of p21 ${ }^{\text {Cip } 1}$ in S phase. J Biol Chem 278: 25752-25757.

Bracken AP, Kleine-Kohlbrecher D, Dietrich N, Pasini D, Gargiulo G, Beekman C, Theilgaard-Monch K, Minucci S, Porse BT, Marine JC, et al. 2007. The Polycomb group proteins bind throughout the INK4A-ARF locus and are disassociated in senescent cells. Genes Dev 21: 525-530.

Brugarolas J, Chandrasekaran C, Gordon JI, Beach D, Jacks T, Hannon GJ. 1995. Radiation-induced cell cycle arrest compromised by p21 deficiency. Nature 377: 552-557.

Buttitta LA, Katzaroff AJ, Perez CL, de la Cruz A, Edgar BA. 2007. A double-assurance mechanism controls cell cycle exit upon terminal differentiation in Drosophila. Dev Cell 12: 631-643.

Cao X, Pfaff SL, Gage FH. 2008. YAP regulates neural progenitor cell number via the TEA domain transcription factor. Genes Dev 22: $3320-3334$.

Clayton JE, van den Heuvel SJ, Saito RM. 2008. Transcriptional control of cell-cycle quiescence during C. elegans development. Dev Biol 313: 603-613.

Correa-Bordes J, Nurse P. 1995. p25 $5^{\text {rum } 1}$ orders S phase and mitosis by acting as an inhibitor of the $\mathrm{p} 34^{c d c 2}$ mitotic kinase. Cell 83: 1001-1009.

Costanzo M, Nishikawa JL, Tang X, Millman JS, Schub O, Breitkreuz K, Dewar D, Rupes I, Andrews B, Tyers M. 2004. CDK activity antagonizes Whi5, an inhibitor of $\mathrm{G}_{1} / \mathrm{S}$ transcription in yeast. Cell 117: 899-913.

Deb DK, Tanaka-Matakatsu M, Jones L, Richardson HE, Du W. 2008. Wingless signaling directly regulates cyclin $\mathrm{E}$ expression in proliferating embryonic PNS precursor cells. Mech Dev 125: 857-864.

de Bruin RA, McDonald WH, Kalashnikova TI, Yates J 3rd, Wittenberg C. 2004. Cln3 activates $G_{1}$-specific transcription via phosphorylation of the SBF bound repressor Whi5. Cell 117: 887-898.

Deng C, Zhang P, Harper JW, Elledge SJ, Leder P. 1995. Mice lacking p21 ${ }^{\mathrm{CIP} 1 / \mathrm{WAF} 1}$ undergo normal development, but are defective in $\mathrm{G}_{1}$ checkpoint control. Cell 82: 675-684.

de Nooij JC, Letendre MA, Hariharan IK. 1996. A cyclin-dependent kinase inhibitor, Dacapo, is necessary for timely exit from the cell cycle during Drosophila embryogenesis. Cell 87: 1237-1247.

Diehl JA, Cheng M, Roussel M, Sherr CJ. 1998. Glycogen synthase kinase$3 \beta$ regulates cyclin D1 proteolysis and subcellular localization. Genes Dev 12: 3499-3511.

Dulic V, Lees E, Reed SI. 1992. Association of human cyclin E with a periodic $\mathrm{G}_{1}-\mathrm{S}$ phase protein kinase. Science 257: 1958-1961.

Duronio RJ, O'Farrell PH. 1995. Developmental control of the $\mathrm{G}_{1}$ to $\mathrm{S}$ transition in Drosophila: Cyclin E is a limiting downstream target of E2F. Genes Dev 9: 1456-1468.

Dyson N. 1998. The regulation of E2F by pRB-family proteins. Genes Dev 12: $2245-2262$.

El-Deiry WS, Tokino T, Velculescu VE, Levy DB, Parsons R, Lin DM, Mercer WE, Kinzler KWV, Vogelstein B. 1993. WAF1, a potential mediator of p53 tumor suppression. Cell 75: 817-825. 
Ewen ME, Sluss HK, Sherr CJ, Matsushime H, Kato J, Livingston DM. 1993. Functional interactions of the retinoblastoma protein with mammalian D-type cyclins. Cell 73: 487-497.

Fay DS, Han M. 2000. Mutations in cye-1, a Caenorhabditis elegans cyclin E homolog, reveal coordination between cell-cycle control and vulval development. Development 127: 4049-4060.

Feldman RMR, Correll CC, Kaplan KB, Deshaies RJ. 1997. A complex of Cdc4p, Skp1p, and Cdc53p/Cullin catalyzes ubiquitination of the phosphorylated CDK inhibitor Siclp. Cell 91: 221-230.

Ferrell JE Jr, Pomerening JR, Kim SY, Trunnell NB, Xiong W, Huang CY, Machleder EM. 2009. Simple, realistic models of complex biological processes: Positive feedback and bistability in a cell fate switch and a cell cycle oscillator. FEBS Lett 583: 3999-4005.

Firth LC, Baker NE. 2005. Extracellular signals responsible for spatially regulated proliferation in the differentiating Drosophila eye. Dev Cell 8: $541-551$.

Franklin DS, Godfrey VL, Lee H, Kovalev GI, Schoonhoven R, ChenKiang S, Su L, Xiong Y. 1998. CDK inhibitors $18^{I N K 4 c}$ and $\mathrm{p} 27^{K I P 1}$ mediate two separate pathways to collaboratively suppress pituitary tumorigenesis. Genes Dev 12: 2899-2911.

Geng Y, Eaton EN, Picon M, Roberts JM, Lundberg AS, Gifford A, Sardet C, Weinberg RA. 1996. Regulation of cyclin E transcription by E2Fs and retinoblastoma protein. Oncogene 12: 1173-1180.

Geng Y, Whoriskey W, Park MY, Bronson RT, Medema RH, Li T, Weinberg RA, Sicinski P. 1999. Rescue of cyclin D1 deficiency by knockin cyclin E. Cell 97: 767-777.

Geng Y, Yu Q, Sicinska E, Das M, Schneider JE, Bhattacharya S, Rideout WM, Bronson RT, Gardner H, Sicinski P. 2003. Cyclin E ablation in the mouse. Cell 114: 431-443.

* Hariharan I. 2013. Signaling pathways that regulate cell division. Cold Spring Harb Perspect Biol (to be published).

Harper JW, Adami GR, Wei N, Keyomarsi K, Elledge SJ. 1993. The p21 Cdk-interacting protein Cip1 is a potent inhibitor of G1 cyclin-dependent kinases. Cell 75: 805-816.

* Harvey KF, Hariharan IK. 2012. The Hippo pathway. Cold Spring Harb Perspect Biol 4: a011288.

Havens CG, Walter JC. 2011. Mechanism of CRL4(Cdt2), a PCNA-dependent E3 ubiquitin ligase. Genes Dev 25: 1568-1582.

* Hemmings BA, Restuccia DF. 2012. PI3K-PKB/Akt pathway. Cold Spring Harb Perspect Biol 4: a011189.

Herrera RE, Sah VP, Williams BO, Makela TP, Weinberg RA, Jacks T. 1996. Altered cell cycle kinetics, gene expression, and $\mathrm{G}_{1}$ restriction point regulation in Rb-deficient fibroblasts. Mol Cell Biol 16: 2402-2407.

Hinds PW, Mittnacht S, Dulic V, Arnold A, Reed SI, Weinberg RA. 1992. Regulation of retinoblastoma protein functions by ectopic expression of human cyclins. Cell 70: 993-1006.

Hong Y, Roy R, Ambros V. 1998. Developmental regulation of a cyclindependent kinase inhibitor controls postembryonic cell cycle progression in Caenorhabditis elegans. Development 125: 3585-3597.

Huang J, Wu S, Barrera J, Matthews K, Pan D. 2005. The Hippo signaling pathway coordinately regulates cell proliferation and apoptosis by inactivating Yorkie, the Drosophila homolog of YAP. Cell 122: 421-434.

Hwang HC, Clurman BE. 2005. Cyclin E in normal and neoplastic cell cycles. Oncogene 24: 2776-2786.

Hwang CY, Lee C, Kwon KS. 2009. Extracellular signal-regulated kinase 2-dependent phosphorylation induces cytoplasmic localization and degradation of p21 ${ }^{\mathrm{Cip} 1}$. Mol Cell Biol 29: 3379-3389.

* Ingham PW. 2012. Hedgehog signaling. Cold Spring Harb Perspect Biol 4: a011221.

Inze D. 2005. Green light for the cell cycle. EMBO J 24: 657-662.

Jacobs JJ, Kieboom K, Marino S, DePinho RA, van Lohuizen M. 1999. The oncogene and Polycomb-group gene bmi-1 regulates cell proliferation and senescence through the ink4a locus. Nature 397: 164-168.

Jones L, Richardson H, Saint R. 2000. Tissue-specific regulation of cyclin E transcription during Drosophila melanogaster embryogenesis. Development 127: 4619-4630.
Kamura T, Hara T, Matsumoto M, Ishida N, Okumura F, Hatakeyama S, Yoshida M, Nakayama K, Nakayama KI. 2004. Cytoplasmic ubiquitin ligase KPC regulates proteolysis of $\mathrm{p}^{27^{\mathrm{Kip} 1}}$ at $\mathrm{G}_{1}$ phase. Nat Cell Biol 6: $1229-1235$.

Kanie T, Onoyama I, Matsumoto A, Yamada M, Nakatsumi H, Tateishi Y, Yamamura S, Tsunematsu R, Matsumoto M, Nakayama KI. 2012. Genetic reevaluation of the role of F-box proteins in cyclin D1 degradation. Mol Cell Biol 32: 590-605.

Kato J-Y, Matsushime H, Hiebert SW, Ewen M, Sherr CJ. 1993. Direct binding of cyclin $\mathrm{D}$ to the retinoblastoma gene product ( $\mathrm{pRb}$ ) and $\mathrm{pRb}$ phosphorylation by the cyclin D-dependent kinase CDK4. Genes Dev 7: 331-342.

Kim M, Nakamoto T, Nishimori S, Tanaka K, Chiba T. 2008a. A new ubiquitin ligase involved in $\mathrm{p} 57^{\mathrm{KIP} 2}$ proteolysis regulates osteoblast cell differentiation. EMBO Rep 9: 878-884.

Kim Y, Starostina NG, Kipreos ET. 2008b. The CRL4Cdt2 ubiquitin ligase targets the degradation of $\mathrm{p} 21^{\mathrm{Cip} 1}$ to control replication licensing. Genes Dev 22: 2507-2519.

Kitagawa M, Higashi H, Jung HK, Suzuki-Takahashi I, Ikeda M, Tamai K, Kato J, Segawa K, Yoshida E, Nishimura S, et al. 1996. The consensus motif for phosphorylation by cyclin D1-Cdk4 is different from that for phosphorylation by cyclin A/E-Cdk2. EMBO J 15: 70607069.

Klein EA, Assoian RK. 2008. Transcriptional regulation of the cyclin D1 gene at a glance. J Cell Sci 121: 3853-3857.

Knoblich JA, Sauer K, Jones L, Richardson H, Saint R, Lehner CF. 1994. Cyclin E controls S phase progression and its down-regulation during Drosophila embryogenesis is required for the arrest of cell proliferation. Cell 77: 107-120.

Koff A, Giordano A, Desai D, Yamashita K, Harper JW, Elledge S, Nishimoto T, Morgan DO, Franza BR, Roberts JM. 1992. Formation and activation of a cyclin E-cdk2 complex during the $G_{1}$ phase of the human cell cycle. Science 257: 1689-1694.

Kominami K-I, Toda T. 1997. Fission yeast WD-repeat protein Pop1 regulates genome ploidy through ubiquitin-proteasome-mediated degradation of the CDK inhibitor Ruml and the S-phase initiator Cdc18. Genes Dev 11: 1548-1560.

* Kopan R. 2012. Notch signaling. Cold Spring Harb Perspect Biol 4: a011213.

Korzelius J, The I, Ruijtenberg S, Prinsen MB, Portegijs V, Middelkoop TC, Groot Koerkamp MJ, Holstege FC, Boxem M, van den Heuvel S. 2011. Caenorhabditis elegans cyclin D/CDK4 and cyclin E/CDK2 induce distinct cell cycle re-entry programs in differentiated muscle cells. PLoS Genet 7: e1002362.

Kotake Y, Cao R, Viatour P, Sage J, Zhang Y, Xiong Y. 2007. pRB family proteins are required for $\mathrm{H} 3 \mathrm{~K} 27$ trimethylation and Polycomb repression complexes binding to and silencing $\mathrm{p} 16^{I N K 4 a}$ tumor suppressor gene. Genes Dev 21: 49-54.

Kozar K, Ciemerych MA, Rebel VI, Shigematsu H, Zagozdzon A, Sicinska E, Geng Y, Yu Q, Bhattacharya S, Bronson RT, et al. 2004. Mouse development and cell proliferation in the absence of D-cyclins. Cell 118: $477-491$.

Lane ME, Sauer K, Wallace K, Jan YN, Lehner CF, Vaessin H. 1996. Dacapo, a cyclin-dependent kinase inhibitor, stops cell proliferation during Drosophila development. Cell 87: 1225-1235.

Lew D, Dulic V, Reed SI. 1991. Isolation of three novel human cyclins by rescue of $\mathrm{G}_{1}$ cyclin $(\mathrm{Cln})$ function in yeast. Cell 66: 1197-1206.

Liou YC, Ryo A, Huang HK, Lu PJ, Bronson R, Fujimori F, Uchida T, Hunter T, Lu KP. 2002. Loss of Pin1 function in the mouse causes phenotypes resembling cyclin D1-null phenotypes. Proc Natl Acad Sci 99: $1335-1340$.

Liu TH, Li L, Vaessin H. 2002. Transcription of the Drosophila CKI gene dacapo is regulated by a modular array of cis-regulatory sequences. Mech Dev 112: 25-36.

Malumbres M, Barbacid M. 2009. Cell cycle, CDKs and cancer: A changing paradigm. Nat Rev Cancer 9: 153-166. 
Malumbres M, Sotillo R, Santamaria D, Galan J, Cerezo A, Ortega S, Dubus P, Barbacid M. 2004. Mammalian cells cycle without the Dtype cyclin-dependent kinases Cdk4 and Cdk6. Cell 118: 493-504.

Matsushime H, Roussel MF, Ashmum RA, Sherr CJ. 1991. Colony-stimulating factor 1 regulates a novel gene (CYL1) during the $\mathrm{G}_{1}$ phase of the cell cycle. Cell 65: 701-713.

Merlo A, Herman JG, Mao L, Lee DJ, Gabrielson E, Burger PC, Baylin SB, Sidransky D. 1995. 5' CpG island methylation is associated with transcriptional silencing of the tumour suppressor p16/CDKN2/MTS1 in human cancers. Nat Med 1: 686-692.

Meyer CA, Jacobs HW, Datar SA, Du W, Edgar BA, Lehner CF. 2000. Drosophila Cdk4 is required for normal growth and is dispensable for cell cycle progression. EMBO J 19: 4533-4542.

Meyer CA, Kramer I, Dittrich R, Marzodko S, Emmerich J, Lehner CF. 2002. Drosophila p27 $7^{\text {Dacapo }}$ expression during embryogenesis is controlled by a complex regulatory region independent of cell cycle progression. Development 129: 319-328.

Minella AC, Loeb KR, Knecht A, Welcker M, Varnum-Finney BJ, Bernstein ID, Roberts JM, Clurman BE. 2008. Cyclin E phosphorylation regulates cell proliferation in hematopoietic and epithelial lineages in vivo. Genes Dev 22: 1677-1689.

* Morrison DK. 2012. MAP kinase pathways. Cold Spring Harb Perspect Biol 4: 011254.

Motokura T, Bloom T, Kim HG, Juppner H, Ruderman JV, Kronenberg HM, Arnold A. 1991. A novel cyclin encoded by a bcll-linked candidate oncogene. Nature 350: 512-515.

Nash P, Tang X, Orlicky S, Chen Q, Gertler FB, Mendenhall MD, Sicheri F, Pawson T, Tyers M. 2001. Multisite phosphorylation of a CDK inhibitor sets a threshold for the onset of DNA replication. Nature 414: 514-521.

Nicholson SC, Nicolay BN, Frolov MV, Moberg KH. 2011. Notch-dependent expression of the archipelago ubiquitin ligase subunit in the Drosophila eye. Development 138: 251-260.

Nishitani H, Shiomi Y, Iida H, Michishita M, Takami T, Tsurimoto T. 2008. CDK inhibitor p21 is degraded by a proliferating cell nuclear antigen-coupled Cul4-DDB1Cdt2 pathway during $S$ phase and after UV irradiation. J Biol Chem 283: 29045-29052.

* Nusse R. 2012. Wnt signaling. Cold Spring Harb Perspect Biol 4: a011163.

Ohtani K, Degregori J, Nevins JR. 1995. Regulation of the cyclin E gene by transcription factor E2F1. Proc Natl Acad Sci 92: 12146-12150.

Ohtsubo M, Roberts JM. 1993. Cyclin-dependent regulation of $G_{1}$ in mammalian fibroblasts. Science 259: 1908-1912.

Ortega S, Malumbres M, Barbacid M. 2002. Cyclin D-dependent kinases, INK4 inhibitors and cancer. Biochim Biophys Acta 1602: 73-87.

Ortega S, Prieto I, Odajima J, Martin A, Dubus P, Sotillo R, Barbero JL, Malumbres M, Barbacid M. 2003. Cyclin-dependent kinase 2 is essential for meiosis but not for mitotic cell division in mice. Nat Genet 35: 25-31.

Pagano M, Tam SW, Theodoras AM, Beer-Romero P, Del Sal G, Chau V, Yew PR, Draetta GF, Rolfe M. 1995. Role of the ubiquitin-proteasome pathway in regulating abundance of the cyclin-dependent kinase inhibitor p27. Science 269: 682-685.

Parisi T, Beck AR, Rougier N, McNeil T, Lucian L, Werb Z, Amati B. 2003. Cyclins E1 and E2 are required for endoreplication in placental trophoblast giant cells. EMBO J 22: 4794-4803.

Pei XH, Bai F, Smith MD, Usary J, Fan C, Pai S-Y, Ho IC, Perou CM, Xiong Y. 2009. CDK inhibitor p18 ${ }^{I N K 4 c}$ is a downstream target of GATA3 and restrains mammary luminal progenitor cell proliferation and tumorigenesis. Cancer Cell 15: 389-401.

Resnitzky D, Gossen M, Bujard H, Reed S. 1994. Acceleration of the $G_{1} / S$ phase transition by expression of cyclins D1 and $\mathrm{E}$ with an inducible system. Mol Cell Biol 14: 1669-1679.

* Rhind N, Russel P. 2012. Signaling pathways that regulate cell division. Cold Spring Harb Perspect Biol 4: a005942.

Roussel MF. 1999. The INK4 family of cell cycle inhibitors in cancer. Oncogene 18: 5311-5317.
Schneider BL, Yang QH, Futcher AB. 1996. Linkage of replication to start by the Cdk inhibitor Sic1. Science 272: 560-562.

Schwob E, Bohm T, Mendenhall MD, Nasmyth K. 1994. The B-type cyclin kinase inhibitor $\mathrm{p} 40^{\mathrm{SIC1}}$ controls the $\mathrm{G}_{1}$ to $\mathrm{S}$ transition in S. cerevisiae. Cell 79: 233-244.

Serrano M, Hannon GJ, Beach D. 1993. A new regulatory motif in cell cycle control causing specific inhibition of cyclin D/CDK4. Nature 366: 704-707.

Sherr CJ. 1996. Cancer cell cycle. Science 274: 1672-1677.

Sherr CJ, Roberts JM. 1995. Inhibitors of mammalian $G_{1}$ cyclin-dependent kinases. Genes Dev 9: 1149-1163.

Sherr CJ, Roberts JM. 2004. Living with or without cyclins and cyclindependent kinases. Genes Dev 18: 2699-2711.

Skowyra D, Craig K, Tyers M, Elledge SJ, Harper JW. 1997. F-box proteins are receptors that recruit phosphorylated substrates to the SCF ubiquitin-ligase complex. Cell 91: 209-219.

Smith AP, Henze M, Lee JA, Osborn KG, Keck JM, Tedesco D, Bortner DM, Rosenberg MP, Reed SI. 2006. Deregulated cyclin E promotes p53 loss of heterozygosity and tumorigenesis in the mouse mammary gland. Oncogene 25: 7245-7259.

Starostina NG, Kipreos ET. 2012. Multiple degradation pathways regulate versatile CIP/KIP CDK inhibitors. Trends Cell Biol 22: 33-41.

Terada Y, Tatsuka M, Jinno S, Okayama H. 1995. Requirement for tyrosine phosphorylation of Cdk4 in $\mathrm{G}_{1}$ arrest induced by ultraviolet irradiation. Nature 376: $358-362$.

van den Heuvel S, Dyson NJ. 2008. Conserved functions of the pRB and E2F families. Nat Rev Mol Cell Biol 9: 713-724.

van Lohuizen M, Verbeek S, Scheijen B, Wientjens E, van der Gulden H, Berns A. 1991. Identification of cooperating oncogenes in $\mathrm{E}^{\mu}-m y c$ transgenic mice by provirus tagging. Cell 65: 737-752.

Wander SA, Zhao D, Slingerland JM. 2011. p27: A barometer of signaling deregulation and potential predictor of response to targeted therapies. Clin Cancer Res 17: 12-18.

Wang TC, Cardiff RD, Zukerberg L, Lees E, Arnold A, Schmidt EV. 1994. Mammary hyperplasia and carcinoma in MMTV-cyclin D1 transgenic mice. Nature 369: 669-671.

Weinberg RA. 1995. The retinoblastoma protein and cell cycle control. Cell 81: 323-330.

Welcker M, Clurman BE. 2008. FBW7 ubiquitin ligase: A tumour suppressor at the crossroads of cell division, growth and differentiation. Nat Rev Cancer 8: 83-93.

Xiong W, Ferrell JE Jr. 2003. A positive-feedback-based bistable "memory module" that governs a cell fate decision. Nature 426: 460-465.

Xiong Y, Connolly T, Futcher B, Beach D. 1991. Human D-type cyclin. Cell 65: 691-699.

Xiong Y, Zhang H, Beach D. 1992. D-type cyclins associate with multiple protein kinases and the DNA replication and repair factor PCNA. Cell 71: 505-514.

Xiong Y, Hannon G, Zhang H, Casso D, Kobayashi R, Beach D. 1993a. p21 is a universal inhibitor of the cyclin kinases. Nature 366: 701-704.

Xiong Y, Zhang H, Beach D. 1993b. Subunit rearrangement of cyclindependent kinases is associated with cellular transformation. Genes Dev 7: 1572-1583.

Yu Q, Geng Y, Sicinski P. 2001. Specific protection against breast cancers by cyclin D1 ablation. Nature 411: 1017-1021.

Yuan Y, Shen H, Franklin DS, Scadden DT, Cheng T. 2004. In vivo selfrenewing divisions of haematopoietic stem cells are increased in the absence of the early $\mathrm{G}_{1}$-phase inhibitor, $\mathrm{p} 18^{\mathrm{INK} 4 \mathrm{C}}$. Nat Cell Biol 6: $436-442$.

Zhao H, Chen X, Gurian-West M, Roberts JM. 2012. Loss of cyclindependent kinase 2 (CDK2) inhibitory phosphorylation in a CDK2AF knock-in mouse causes misregulation of DNA replication and centrosome duplication. Mol Cell Biol 32: 1421-1432.

Zindy F, Quelle DE, Roussel MF, Sherr CJ. 1997. Expression of the p16 $6^{\text {INK4a }}$ tumor suppressor versus other INK4 family members during mouse development and aging. Oncogene 15: 203-211. 


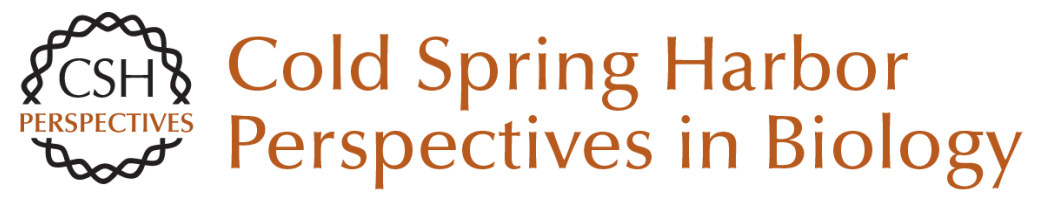

\section{Signaling Pathways that Control Cell Proliferation}

Robert J. Duronio and Yue Xiong

Cold Spring Harb Perspect Biol 2013; doi: 10.1101/cshperspect.a008904

Subject Collection Signal Transduction

Cell Signaling and Stress Responses Gökhan S. Hotamisligil and Roger J. Davis

Protein Regulation in Signal Transduction Michael J. Lee and Michael B. Yaffe

Synaptic Signaling in Learning and Memory Mary B. Kennedy

Vertebrate Reproduction Sally Kornbluth and Rafael Fissore

Signaling in Lymphocyte Activation Doreen Cantrell

Signaling in Muscle Contraction Ivana Y. Kuo and Barbara E. Ehrlich

Toll-Like Receptor Signaling Kian-Huat Lim and Louis M. Staudt

Signaling Pathways that Regulate Cell Division Nicholas Rhind and Paul Russell
Second Messengers

Alexandra C. Newton, Martin D. Bootman and John D. Scott

Signals and Receptors Carl-Henrik Heldin, Benson Lu, Ron Evans, et al.

Cell Death Signaling Douglas $R$. Green and Fabien Llambi

Signaling Networks that Regulate Cell Migration Peter Devreotes and Alan Rick Horwitz

Signaling Networks: Information Flow, Computation, and Decision Making Evren U. Azeloglu and Ravi lyengar

Signal Transduction: From the Atomic Age to the Post-Genomic Era Jeremy Thorner, Tony Hunter, Lewis C. Cantley, et al.

Signaling by the TGF $\beta$ Superfamily Jeffrey L. Wrana

Subversion of Cell Signaling by Pathogens Neal M. Alto and Kim Orth

For additional articles in this collection, see http://cshperspectives.cshlp.org/cgi/collection/

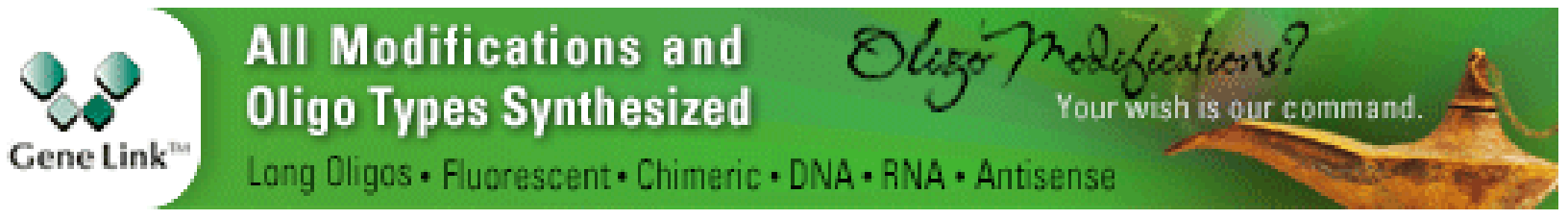

Copyright @ 2013 Cold Spring Harbor Laboratory Press; all rights reserved 